\title{
OBJEKTIVITAS BERITA BENCANA GEMPA LOMBOK DI MEDIA ONLINE
}

\author{
Geri Suratno, Indah Suryawati \\ geri.suratno@budiluhur.ac.id; indah.suryawati@budiluhur.ac.id \\ Universitas Budi Luhur
}

\begin{abstract}
An earthquake with 6.4 on the Richter scale that rocked Lombok, West Nusa Tenggara and parts of Bali on July 29, 2018, really attracted the attention of the public. Regarding coverage of natural disasters, the easiest alternative media to get access to information is online media. In fact, the public found that news through online media tended to ignore objectivity, such as elements of completeness, accuracy, fairness, neutrality just to get the publication fastly. The purposes of this study were first, to find out the objectivity of the news presented by Viva.co.id, Kompas.com, and Tribunnewsbali.com during the earthquake and postearthquake disaster in Lombok from 29 July to 29 August 2018, and the second, to describe the roles of Viva.co.id, Kompas.com, and Tribunnewsbali.com in reporting the earthquake in Lombok during this period. The focus of online media content analysis is on the elements of objectivity, truth, factual, accuracy, complete and neutrality. The research method used is the content analysis method using a quantitative approach. The object of this research was the Lombok earthquake news reported by Viva.co.id, Kompas.com and Tribunnewsbali.com period July 29 to August 29, 2018. The results showed that Viva.co.id, Kompas.com and Tribunnewsbali.com prioritized sub-dimensions truth in upholding objectivity. Where the sub dimensions of truth are divided into three elements, those are factual, accuracy and complete. But Viva.co.id and Tribunnewsbali.com ignored the subdimensions of neutrality. While kompas.com didn't ignore the sub-dimensions of neutrality. Even though the sub-dimensions of neutrality are part of the dimension of objectivity.
\end{abstract}

Keywords: Online Media, Content Analysis, Lombok Earthquake News, Objectivity

\begin{abstract}
ABSTRAK
Gempa bumi berkekuatan 6,4 pada skala richter yang mengguncang Lombok, Nusa Tenggara Barat dan sebagian wilayah di Bali pada tanggal 29 Juli 2018 lalu, sungguh menyedot perhatian masyarakat. Terkait liputan bencana alam, alternatif media yang paling mudah dalam mendapat akses informasi adalah media online. Faktanya, masyarakat menemukan bahwa berita melalui media online cenderung mengabaikan objektivitas, seperti unsur kelengkapan, akurasi, keadilan, hingga netralitas hanya untuk mengejar kecepatan terbit saja. Tujuan penelitian ini adalah pertama, untuk mengetahui objektivitas berita yang disajikan Viva.co.id,
\end{abstract}


Kompas.com, dan Tribunnewsbali.com saat terjadinya bencana gempa maupun pasca terjadinya bencana gempa di Lombok periode 29 Juli hingga 29 Agustus 2018, dan kedua, untuk mendeskripsikan peran Viva.co.id, Kompas.com, dan Tribunnewsbali.com dalam memberitakan bencana gempa Lombok selama periode tersebut. Metode penelitian yang digunakan adalah metode analisis isi dengan menggunakan pendekatan kuantitatif. Objek penelitian ini adalah berita gempa Lombok yang diberitakan Viva.co.id, Kompas.com dan Tribunnewsbali.com periode 29 Juli hingga 29 Agustus 2018. Fokus analisis isi media online pada dimensi obyektivitas yang mencakup sub demensi kebenaran (faktual, akurasi, lengkap) dan sub dimensi netralitas. Hasil penelitian menunjukkan bahwa Viva.co.id, Kompas.com dan Tribunnewsbali.com mengutamakan sub dimensi kebenaran dalam menegakkan obyektivitas, yaitu unsur faktual, akurasi dan lengkap. Namun, Viva.co.id dan Tribunnewsbali.com mengabaikan sub dimensi netralitas. Sedangkan kompas.com tidak mengabaikan sub dimensi netralitas. Padahal sub dimensi netralitas adalah bagian dari dimensi objektivitas. Temuan lain, Viva.co.id, Kompas.com, dan Tribunnewsbali.com sudah menjalankan peran informatif dalam memberitakan bencana gempa Lombok untuk memenuhi kebutuhan informasi khalayaknya.

Kata kunci: Media Online, Analisis isi, Berita Gempa Lombok, Objektivitas.

\section{PENDAHULUAN}

Peristiwa gempa bumi berkekuatan 6,4 pada skala richter yang mengguncang Lombok, Nusa Tenggara Barat dan sebagian wilayah di Bali pada tanggal 29 Juli 2018 silam, sungguh menyedot perhatian masyarakat Indonesia. Gempa besar susulan pun beberapa kali terjadi yang kemudian menambah jumlah korban jiwa, kerusakan bangunan dan kerugian ekonomi. Pemerintah Indonesia menyadari bahwa masalah bencana harus ditangani secara serius sejak terjadinya gempa bumi dan disusul tsunami yang menerjang Aceh dan sekitarnya pada tahun 2004 silam.

Gempa pertama yang berkekuatan 6,4 SR (29/7/2018) yang kemudian disusul gempa berikutnya berkekuatan 7 SR (5/8/2018), 6,5 SR $(19 / 8 / 2018$ siang) dan $6,9 \quad$ SR
(19/8/2018 malam) menyebabkan 506 orang meninggal dunia, 431.416 orang mengungsi, 74.361 unit rumah rusak hingga kerusakan infrastruktur. Diperkirakan kerusakan dan kerugian yang dialami akibat gempa berulang ini mencapai $\mathrm{Rp} \quad 7,7$ trilyun (https://bnpb.go.id/potensi-nasionalmasih-mampu-mengatasi-bencanalombok-tanpa-harus-menyatakanbencana-menyatakan-bencananasional).

Berdasarkan data daftar rawan bencana yang dikeluarkan oleh Badan Nasional Penanggulangan Bencana pada tahun 2010 menyebutkan, dari 386 kabupaten/kota yang ada di Indonesia terdapat 175 kabupaten/kota yang tergolong daerah rawan bencana tinggi, sebanyak 179 kabupaten/kota yang masuk kategori daerah rawan bencana 
sedang, dan sejumlah 32 kabupaten/kota yang masuk kategori rawan bencana rendah. Tingkat kerawanan itu menjadi aktual berdasarkan International Strategy for Reduction 2006-2009 World Disaster Reduction Campaign UNESCO pada tahun 2005, di mana Indonesia menempati urutan ke-7 di dunia dalam hal tingkat kerusakan dan kerugian yang diakibatkan oleh bencana alam yang terjadi (Pramudhiarta dan Adhistya Erna Permanasari, 2014).

Di sini peran media (pers) sangat penting dalam memberitakan terjadinya bencana alam. Sebab media sebagai saluran yang efektif untuk menyebarkan informasi terkait bencana alam ke berbagai penjuru dunia. Seperti informasi mengenai jenis bencana, kapan terjadinya bencana, lokasi terjadinya bencana, identifikasi tanda-tanda alam awal terjadinya bencana, jumlah korban jiwa dan kerugian material, dampak yang dirasakan dan kebutuhan korban bencana alam, bagimana proses evakuasi korban bencana, hingga informasi tentang penyelamatan yang dilakukan pihak pemerintah. Semua informasi tersebut dapat terekam dan tersampaikan melalui pemberitaan media.

Terkait liputan bencana alam, alternatif media yang paling mudah dalam mendapat akses informasi atau berita adalah media online. Media online selalu memberikan liputan yang telah terjadi bahkan liputan yang paling terkini. Liputan yang dibuat oleh media lebih banyak mengarah kepada pemberitaan yang bersifat traumatis dan dramatik. Pemberitaan yang sering kali muncul dalam media adalah isak tangis, kesedihan, kekecewaan, jumlah korban dan kisah tragis lainnya yang semua itu memberikan kesan yang mencekam (Gama, 2010:8-18). Media online merupakan hasil dari kajian teknologi komunikasi yang menawarkan kepada pengguna sebagai media yang berperan sebagai alat komunikasi interpersonal atau juga disebut media interaktif, di mana media memungkinkan partisipasi aktif baik penerima maupun pengirim. Media online dapat menampung berita seperti tulisan, gambar, suara, dan video. Berbeda dengan media cetak yang hanya menampilkan tulisan dan gambar. Online dapat didefinisikan sebagai bahasa internet yang berarti informasi dapat diakses di mana saja dan kapan saja selama terhubung dengan jaringan internet (Aisyah, Pantow dan Koagouw, 2015).

Faktanya, masyarakat menemukan bahwa berita melalui media online cenderung mengabaikan unsur kelengkapan, ketepatan (akurasi), keadilan, hingga netralitas hanya untuk mengejar kecepatan terbit saja. Unsur kecepatan perlu pula dibarengi dengan sikap objektif wartawan dalam menulis berita. Dengan sikap objektifnya tersebut, berita yang ia buat pun akan objektif, artinya berita yang dibuat selaras 
dengan kenyataan/fakta, tidak berat sebelah, bebas dari prasangka.

Objektivitas adalah konsep yang abstrak. Agar objektivitas dapat diukur, maka konsep ini harus dioperasionalisasikan. Salah satu teknik membuat agar konsep ini operasional adalah dengan menggunakan model pohon (tree). Di sini konsep "objektivitas" diturunkan lebih kecil secara terus menerus hingga diperoleh indikator yang spesifik. Lewat indikator yang spesifik inilah konsep objektivitas dapat diukur (Eriyanto, 2011:194).

Skema Westerstahl (dikutip dari McQuail, 1992) untuk menurunkan konsep objektivitas.

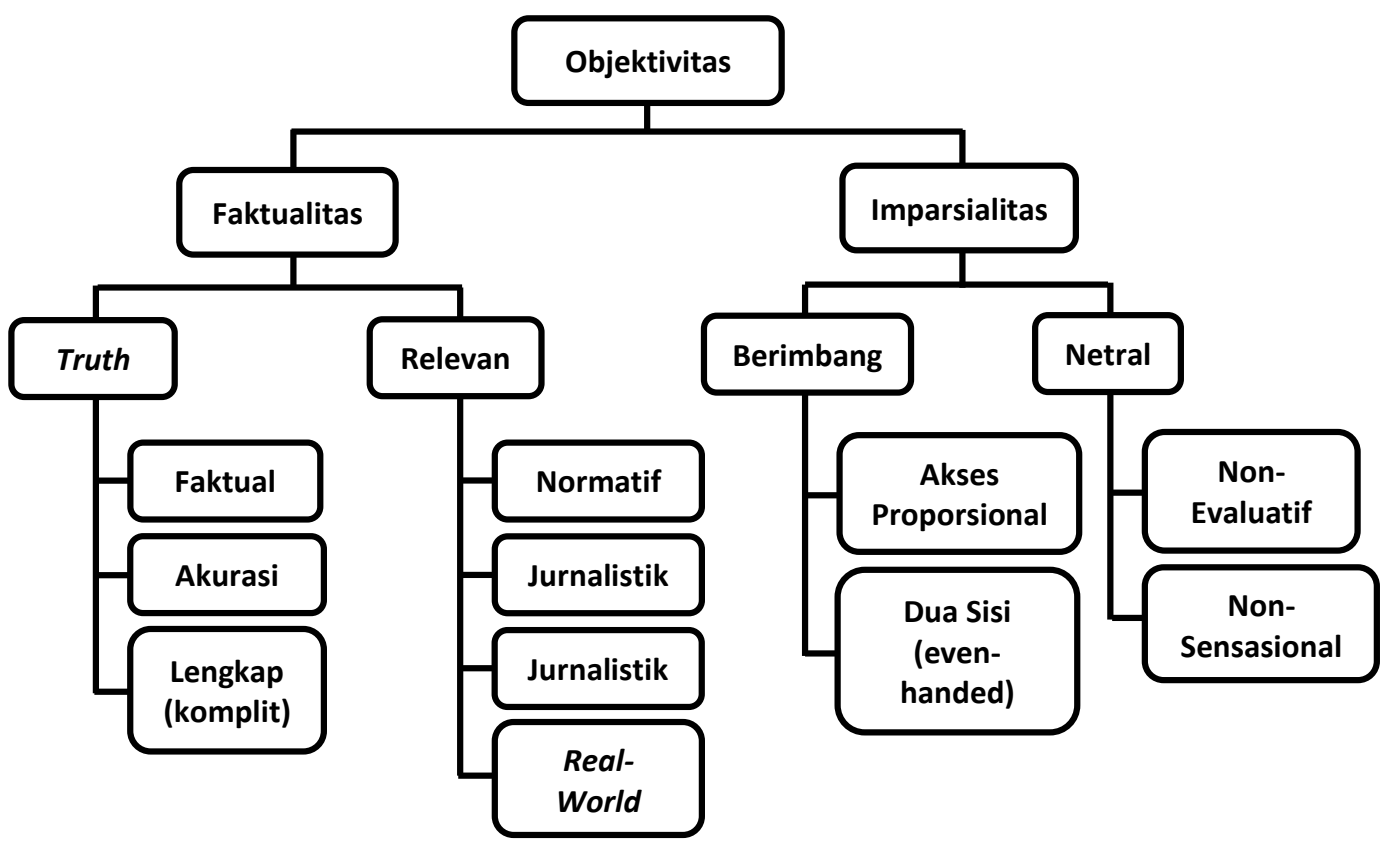

\section{Gambar 1 Konsep Objektivitas}

(Sumber: Eriyanto, 2011)

Objektivitas dalam pandangan yang sempit, mengambil keuntungan dari wartawan yang bersikeras bahwa berita bukanlah berita sampai ada seseorang yang berwenang mengatakannya. Dengan kata lain, sebuah berita dikatakan obyektif jika peristiwa/fakta yang diliputnya menyertakan kutipan wawancara dari pejabat resmi publik yang terkait dengan peristiwa tersebut. Jika tidak menyertakan sumber resmi maka sebagus apa pun nilai berita yang diangkat oleh wartawan akan tetap dianggap berita tersebut tidak obyektif. Artinya, unsur kebenaran suatu peristiwa/fakta tidaklah cukup dijadikan sebagai berita.

Namun seiring waktu, objektivitas dalam pandangan sempit mulai ditinggalkan. Sebab banyak wartawan dalam pekerjaannya 
kemudian melihat unsur adil (fairness) sebagai prinsip jurnalistik yang penting untuk dikedepankan selain unsur kebenaran (truth). Obyektif tidak mati dalam pemberitaan, sehingga standar kejujuran pun lebih diutamakan. Daripada sekedar "membawa berita" (bringing the news), media berkembang ke arah 'menjelaskan berita" (explaining the news). Dengan kata lain, gaya penulisan interpretatif reporting cenderung lebih disukai (Ishwara, 2011:69).

Lawan objektif adalah subjektif, yaitu sikap yang diwarnai oleh prasangka pribadi. Depth reporting (pemberitaan mendalam) maupun investigative reporting (pemberitaan investigasi) haruslah objektif, meski boleh memiliki suatu fokus pandangan (point of view). Hal ini seringkali menjadi penyebab timbulnya masalah karena media online sangat memungkinkan penyebaran informasi menjadi lebih cepat dibanding media lainnya, tapi wartawan cenderung mengabaikan isi berita yang obyektif dan komprehensif. Unsur kecepatan didahulukan oleh media online dan mengabaikan prinsip-prinsip dasar jurnalistik sebagaimana yang cenderung dikedepankan oleh media cetak dan media elektronik.

Pemberitaan bencana gempa di Lombok diberitakan secara intensif di Viva.co.id, Kompas.com dan Tribunnewsbali.com.

Bahkan peristiwa gempa Lombok menjadi tranding topic di ketiga media online tersebut. Ini terlihat dari jumlah berita yang diproduksi mulai awal terjadinya bencana gempa maupun pasca gempa hingga akhir Agustus 2018 ini. Adapun jumlah berita gempa Lombok yang diberitakan Viva.co.id sebanyak 258 berita, Kompas.com sebanyak 233 berita dan Tribunnewsbali.com sebanyak 150 berita.

Tingginya jumlah pemberitaan yang dilakukan Viva.co.id, Kompas.com, dan Tribunnewsbali.com. terkait bencana gempa di Lombok menunjukkan bahwa ketiga media tersebut menganggap musibah ini sebagai informasi penting yang perlu diberitakan pada khalayak mereka hingga kurun waktu tertentu. Menurut McComb dan Shaw (dikutip dari McQuail da Sven Windahl, 1996:104), khalayak tidak hanya mempelajari berita dan hal-hal lain melalui media massa, tetapi juga mempelajari seberapa besar arti penting diberikan pada suatu isu atau topik dari cara media massa memberikan penekanan terhadap topik tertentu.

Nilai berita menjadi ukuran yang berguna, atau yang biasa diterapkan, untuk menentukan layak berita (newsworthy). Peristiwaperistiwa yang memiliki nilai berita misalnya yang mengandung konflik, bencana dan kemajuan, dampak, kemasyhuran, segar dan kedekatan, keganjilan, human interest, seks, dan 
aneka nilai lainnya (Ishwara, 2011:76-77). Nilai berita mana yang mesti diutamakan dalam setiap berita, Indah Suryawati (2011) menjelaskan bahwa bukan semata-mata bergantung kepada wartawan sebagai pihak yang bertugas mencari dan menulis berita. Melainkan bergantung kepada media di mana wartawan itu bekerja dan karateristik khalayak dari medianya.

Adapun periode pemilihan berita untuk diteliti adalah mulai dari saat terjadinya gempa Lombok pertama kali, yaitu tanggal 29 Juli 2018 hingga 29 Agustus 2018 (periode sebulan). Ini dikarenakan selama periode tersebut Viva.co.id, Kompas.com dan Tribunnewsbali.com masih memberitakan bencana gempa Lombok. Sementara media online lainnya tak melakukan hal yang sama sebagaimana dilakukan Viva.co.id, Kompas.com, dan Tribunnewsbali.com. Hal inilah yang melatarbelakangi penelitian tentang berita bencana gempa Lombok yang termuat di Viva.co.id, Kompas.com, dan Tribunnewsbali.com.

Penulisan ini membahas tentang objektivitas berita yang disajikan Viva.co.id, Kompas.com, dan Tribunnewsbali.com saat terjadinya bencana gempa maupun pasca terjadinya bencana gempa di Lombok periode 29 Juli hingga 29 Agustus 2018. Selain itu, untuk mendeskripsikan peran Viva.co.id, Kompas.com,
Tribunnewsbali.com

dalam memberitakan bencana gempa Lombok selama periode tersebut.

\section{METODE PENELITIAN}

Riset kuantitatif adalah riset yang menggambarkan atau menjelaskan suatu masalah yang hasilnya dapat digeneralisasikan. Dalam riset kuantitatif, periset dituntut bersikap objektif dan memisahkan diri dari data. Dengan demikian tidak terlalu mementingkan kedalaman data atau analisis. Periset lebih mementingkan aspek keluasan data sehingga data atau riset dianggap merupakan representasi dan seluruh populasi (Kriyantono, 2006:55).

Metode penelitian yang digunakan dalam penelitian ini adalah metode analisis isi (content analysis) dengan menggunakan pendekatan kuantitatif. Analisis isi kuantitatif dapat didefinisikan sebagai suatu teknik penelitian ilmiah yang ditujukan untuk mengetahui gambaran karakteristik isi dan menarik dari isi. Analisis isi ditujukan untuk mengidentifikasi secara sistematis isi komunikasi yang tampak (manifest), dan dilakukan secara objektif, valid, reliabel, dan dapat direplikasi (Sobur, 2001:70).

Objek penelitian ini adalah berita gempa Lombok yang diberitakan Viva.co.id, Kompas.com, dan Tribunnewsbali.com periode 29 Juli hingga 29 Agustus 2018. Adapun jumlah berita gempa Lombok yang diberitakan Viva.co.id sebanyak 258 
berita, Kompas.com sebanyak 233 berita dan Tribunnewsbali.com sebanyak 150 berita. Dari periode yang ditetapkan sebelumnya, peneliti hanya mengambil periode tanggal 5 Agustus hingga 11 Agustus dengan masing-masing jumlah berita sebagai berikut Viva.co.id sebanyak 133 berita, Kompas.com sebanyak 113 berita, dan Tribunnewsbali.com sebanyak 106 berita.

Adapun unit analisis yang dianalisis dalam penelitian ini adalah dimensi obyektivitas yang meliputi sub dimensi kebenaran dan sub dimensi netralitas. Untuk sub dimensi kebenaran yang dianalisis adalah 1) unsur faktual, 2) akurasi dan 3) lengkap. Sedangkan sub dimensi netralitas yang dianalisis adalah 1) unsur tidak sensasional atau dramatis, 2) tidak memberikan penekanan tertentu, 3) tidak menimbulkan rasa takut yang berlebihan.
Analisis data dalam penelitian ini dilakukan dengan melakukan pengawasan terhadap keseluruhan isi pesan dengan standar penilaian yang jelas, yakni mencocokkan indikator yang diturunkan dari konsep objektivitas pemberitaan bencana gempa Lombok dengan berita yang menjadi sampel penelitian. Karena analisis ini mencari kecenderungankecenderungan yang ada dari berbagai sisi berita berita Viva.co.id, Kompas.com, dan Tribunnewsbali.com tentang terjadinya bencana gempa maupun pasca terjadinya bencana gempa Lombok, maka analisis isi secara sadar ditujukan kepada tercapainya tujuan penelitian.

\section{HASIL DAN PEMBAHASAN}

\section{A. Unsur Akurasi Menjadi Bagian Terpenting Dari Dimensi Objektivitas}

Tabel 1

Unsur Akurasi dalam Berita Bencana Gempa Lombok di Tiga Media Online Periode 5 - 11 Agustus 2018

\begin{tabular}{|l|l|c|c|c|c|c|c|}
\hline No. & \multicolumn{1}{|c|}{ Butir } & \multicolumn{2}{c|}{ Viva.co.id } & \multicolumn{2}{c|}{ Kompas.com } & \multicolumn{2}{c|}{ Tribunnewsbali.com } \\
\cline { 3 - 8 } & & $\mathbf{F}$ & $\mathbf{\%}$ & $\mathbf{F}$ & $\mathbf{\%}$ & $\mathbf{F}$ & $\mathbf{\%}$ \\
\hline 1. & $\begin{array}{l}\text { Ada kesesuaian judul } \\
\text { dengan isi berita }\end{array}$ & 130 & $\begin{array}{c}98 \\
\%\end{array}$ & 107 & $97 \%$ & 105 & $99 \%$ \\
\hline 2. & $\begin{array}{l}\text { Tidak ada kesesuaian } \\
\text { judul dengan isi berita }\end{array}$ & 3 & $2 \%$ & 6 & $3 \%$ & 1 & $1 \%$ \\
\hline 3. & Pencantuman waktu & 129 & $\begin{array}{c}97 \\
\%\end{array}$ & 113 & $100 \%$ & 94 & $87 \%$ \\
\hline 4. & $\begin{array}{l}\text { Tidak ada } \\
\text { pencantuman waktu }\end{array}$ & 4 & $3 \%$ & 0 & 0 & 12 & $13 \%$ \\
\hline 5. & $\begin{array}{l}\text { Ada kesalahan dalam } \\
\text { penulisan berita }\end{array}$ & 99 & $\begin{array}{c}74 \\
\%\end{array}$ & 30 & $26 \%$ & 94 & $87 \%$ \\
\hline 6. & $\begin{array}{l}\text { Tidak ada kesalahan } \\
\text { dalam penulisan berita }\end{array}$ & 34 & $\begin{array}{c}26 \\
\%\end{array}$ & 83 & $74 \%$ & 12 & $13 \%$ \\
\hline
\end{tabular}

Sumber: Diolah dari Data Primer (2019) 


\begin{abstract}
Berdasarkan temuan hasil penelitian pada Viva.co.id, Kompas.com, dan Tribunnewsbali.com, media online ini sama-sama mengedepankan sub dimensi kebenaran (truth) dalam menulis berita gempa Lombok. Yang membedakan dari ketiga media online ini adalah penekanan unsur-unsur yang menjadi indikator dalam mengukur ada atau tidak adanya muatan kebenaran.
\end{abstract}

\section{Viva.co.id}

dan

Tribunnewsbali.com mengutamakan unsur kesesuaian judul dengan isi berita dibanding unsur lainnya dalam sub dimensi kebenaran. Tingkat kesesuaian judul dengan isi berita pada Viva.co.id sebesar $98 \%$; sedangkan Tribunnewsbali.com sebesar $99 \%$. Namun sebenarnya Kompas.com pun tidak mengabaikan unsur ini, karena terbukti kesesuaian judul dengan isi berita pada Kompas.com mencapai $97 \%$. Artinya ketiga media online ini tidak mengabaikan unsur kesesuaian judul dengan isi berita dalam berita gempa Lombok sebagai bagian dalam menegakkan unsur kebenaran (truth). Hanya saja Kompas.com tidak menempatkan indikator tersebut sebagai unsur pertama untuk mengukur kebenaran, melainkan unsur pencantuman waktu di setiap berita bencana gempa Lombok tanpa terkecuali. Ini terlihat dari hasil penelitian yang menemukan tak ada satu pun berita gempa Lombok di Kompas.com mencantumkan waktu terjadinya peristiwa/fakta yang diliputnya. Dari 113 berita yang menjadi objek penelitian, seluruhnya mencantumkan waktu kapan peristiwa itu terjadi.

Apa yang dilakukan Viva.co.id, Kompas.com dan Tribunnewsbali.com merupakan bagian dari penegakan unsur akurasi. Di mana akurasi itu sendiri merupakan salah satu unsur dari sub dimensi kebenaran dan bagian dari dimensi objektivitas. Menurut Ishawara (2011:39), akurasi bukan hanya menjadi suatu isu editorial (editorial issue). Akurasi adalah suatu nilai dasar (fundamental value) yang harus selalu diterapkan tanpa syarat, baik oleh wartawan maupun editor. Akurat berarti, kita harus mendapatkan informasi yang pasti, yang tidak bisa dibantah. Karena wartawan bukan hanya harus mendapatkan fakta yang benar, tetapi juga fakta yang betul. Wartawan harus sadar bahwa menduga, mengira, apalagi ceroboh dalam memberitakan suatu informasi maka ia dapat mendatangkan bencana bagi karier kewartawanannya.

Namun hasil penelitian menemukan bahwa secara keseluruhan penulisan berita di Viva.co.id dan di Tribunnewsbali.com sebagian besar terdapat kesalahan. Dalam kesalahan penulisan tersebut, Tribunnewsbali.com membuat kesalahan sebanyak $87 \%$ dan hanya 
$27 \%$ yang tidak ada kesalahan dalam penulisan berita. Sedangkan Viva.co.id sebanyak $74 \%$ kesalahan dalam penulisan berita, dan $26 \%$ tidak ada kesalahan dalam penulisan berita. Sebaliknya, Kompas.com mempunyai kesalahan dalam penulisan berita hanya sebesar $26 \%$, dan tidak ada kesalahan dalam penulisan berita sebesar $74 \%$.

Prinsip akurasi memegang peranan penting dalam pemberitaan. Bukan saja akurat dalam hal mengungkapkan penyebab kecelakaan dan bencana alam, melainkan juga akurat dalam penyebutan waktu kejadian, tempat, nama, serta jumlah korban. Tetapi yang tak kalah pentingnya adalah akurat dalam pengungkapan posisi dan situasi terakhir dari kejadian bencana itu sendiri.

Pentingnya akurasi ini sebenarnya tidak perlu diperdebatkan lagi, sebab berita yang tidak akurat dapat mengakibatkan tuntutan hukum bagi media bersangkutan, dan media yang tidak akurat akan kehilangan kredibilitas. Unsur kredibilitas memang harus menjadi pegangan bagi apa yang diucapkan, dilakukan, dan ditulis oleh wartawan. Media yang tidak kredibel akhirnya akan kehilangan prestise. Dan media yang seperti ini lambat laun akan ditinggalkan oleh khalayaknya. Tentu saja Viva.co.id, Kompas.com dan Tribunnewsbali.com tak menginginkan hal tersebut terjadi pada media mereka, sehingga ketiganya tetap konsisten menegakkan akurasi dalam setiap pemberitaannya terkait bencana gempa di Lombok.

Akurasi juga menyangkut tentang standar etika, disamping standar professional dan operasional yang harus diterapkan oleh para wartawan. Memang, akurasi ini bisa menjadi penganggu wartawan yang harus bekerja di bawah tekanan waktu (deadline). Tekanan untuk menyampaikan berita kepada publik selagi masih hangat kerap menyebabkan terjadinya kekeliruankekeliruan dalam isi berita. Karena itu banyak ruang redaksi yang menempelkan peringatan dari International News Service: 'Get It First, But First Get It Right (Jadilah yang pertama untuk mendapatkan berita, tetapi yang utama berita itu harus benar)." Dengan kata lain, kewajiban media adalah mendapatkan yang benar dulu, bukan menjadi yang pertama. Karena prioritas utama media adalah mendapatkan yang benar (Ishwara, 2011:40).

Di sinilah letak kesulitannya bagi media online yang lebih mengutamakan kecepatan. Dari pengalaman di lapangan, wartawan harus tahu bahwa bila mendahulukan kecepatan maka ketelitian sering terabaikan. Begitu juga sebaliknya, jika mendahulukan ketelitian maka wartawan tidak bisa cepat menyiarkan informasi. Sebab ketelitian membutuhkan waktu, 
apalagi ketika meliput pada minggu pertama pascabencana yang cenderung dipenuhi jumlah korban jiwa yang terus bertambah dari waktu ke waktu. Data yang akurat masih sulit untuk diperoleh mengingat aparat pemerintah sebagai salah satu sumber resmi masih disibukkan dengan upaya pertolongan pada korban bencana, termasuk menolong keluarga mereka sendiri yang turut menjadi korban bencana. Dalam konteks tersebut, pemilihan sumber berita menjadi sangat penting. Berlaku prinsip, kecepatan informasi sesungguhnya bermula dari kecepatan dalam memilih sumber berita.

Sesungguhnya khalayak membutuhkan informasi yang tak sekadar faktual tapi juga akurat terkait kapan peristiwa atau fakta tersebut terjadi. Pencantuman waktu sangat berpengaruh dalam pemberitaan media online. Hal ini karena media online adalah media yang sangat mengutamakan kecepatan penyampaian informasi namun sering mengabaikan keakuratan. Dengan memberikan pencantuman waktu pada setiap laporan peristiwa/kejadian sebagaimana dilakukan Kompas.com memungkinkan khalayak untuk mendapatkan informasi yang akurat. Dan media online memiliki tuntutan untuk menyediakan akses penuh terhadap informasi-informasi yang benar dan akurat, sebagaimana yang dilakukan media cetak dan media elektronik. Sehingga informasi yang diberitakan dapat menjadi pegangan masyarakat saat berhadapan dengan bencana alam. Bahkan informasi yang disediakan media online akan menjadi semacam peringatan dini bagi masyarakat yang mengingatkan bahwa masyarakat berada di wilayah yang rawan bencana, dan harus waspada bersiap setiap saat untuk menghadapinya.

\section{B. Unsur Lengkap Untuk Memperkuat Objektivitas}

Tabel 2

Unsur Lengkap dalam Berita Bencana Gempa Lombok di Tiga Media Online Periode 5 - 11 Agustus 2018

\begin{tabular}{|l|l|c|c|c|c|c|c|}
\hline \multirow{2}{*}{ No. } & \multicolumn{1}{|c|}{ Butir } & \multicolumn{2}{c|}{ Viva.co.id } & \multicolumn{2}{c|}{ Kompas.com } & \multicolumn{2}{c|}{ Tribunnewsbali.com } \\
\cline { 3 - 8 } & & F & \% & F & \% & F & \% \\
\hline 1. & $\begin{array}{l}\text { Penggunaan 5 W + 1 } \\
\text { H }\end{array}$ & 122 & $\begin{array}{c}92 \\
\%\end{array}$ & 108 & $95 \%$ & 85 & $80 \%$ \\
\hline 2. & $\begin{array}{l}\text { Tak ada penggunaan 5 } \\
\text { W + 1 H }\end{array}$ & 11 & $8 \%$ & 5 & $5 \%$ & 21 & $20 \%$ \\
\hline 3. & $\begin{array}{l}\text { Penggunaan kutipan } \\
\text { wawancara }\end{array}$ & 114 & $\begin{array}{c}86 \\
\%\end{array}$ & 107 & $94 \%$ & 102 & $96 \%$ \\
\hline 4. & $\begin{array}{l}\text { Tak ada penggunaan } \\
\text { kutipan wawancara }\end{array}$ & 19 & $\begin{array}{l}14 \\
\%\end{array}$ & 6 & $6 \%$ & 4 & $4 \%$ \\
\hline
\end{tabular}

Sumber: Diolah dari data Primer (2019) 
Temuan berikutnya Viva.co.id (92 \%) dan Kompas.com (95\%) cenderung mengutamakan penggunaan $5 \mathrm{~W}+1 \mathrm{H}$ dalam menyajikan berita gempa Lombok. Sementara Tribunnewsbali.com menggunakan $5 \mathrm{~W}+1 \mathrm{H}$ dalam 80 persen beritanya. Penyajian berita dengan menggunakan rumus $5 \mathrm{~W}+1 \mathrm{H}$ sama artinya bahwa media tersebut telah menyusun peristiwa atau fakta terkait gempa di Lombok secara lengkap.

Sebagaimana diketahui, dalam praktek jurnalistik para pakar memberikan pedoman dalam menulis berita dengan menggunakan formula (rumusan) $5 \mathrm{~W}+1 \mathrm{H}$. Pedoman ini disebut syarat kelengkapan sebuah berita. Bahkan rumusan $5 \mathrm{~W}+1 \mathrm{H}$ masih merupakan syarat wajib untuk menentukan bagus atau tidaknya berita yang disajikan. Sebab peristiwa atau fakta sebagus apa pun namun disusun tanpa memenuhi kaidah $5 \mathrm{~W}+1 \mathrm{H}$ akan menjadi sebuah berita yang tidak bagus (bad news). Sebaliknya, peristiwa atau fakta biasa saja tapi disusun secara lengkap dengan memenuhi kaidah $5 \mathrm{~W}+1 \mathrm{H}$ bisa menjelma menjadi berita bagus (good news).

Jika sebelumnya kita telah menyinggung bahwa jurnalistik online mempunyai kekhasan dari sisi gaya penulisan dibanding jurnalistik konvensional. Robert Niles dalam bukunya berjudul, How To Write For The Web: The Online Journalism Review, menjelaskan bahwa gaya penulisan oleh jurnalis online adalah short (ringkas) - the shorter the better; active voice (menggunakan kalimat aktif); strong verbs (menggunakan kata kerja yang kuat); contextual hyperlinking (melengkapi informasi dengan tautan yang terkait sehingga memungkinkan pembaca memperkaya pengetahuan dan informasi pendukung); use formatting (menggunakan variasi tampilan huruf atau kalimat) misalnya dengan menggunakan daftar (list), header tebal, dan kutipan (blockquotes); dan easy to read (mudah dibaca). (Fernando Lumowa, Media Online: Teknik Dasar Penulisan Berita, Arlikel dan Bahasa Jurnalislik,

sulut.kemenag.go.id/file/file/humas/zu vw 1339679719. ppsx diakses pada 04 Mei 2017 pkl 09:04 WIB). Ini dimungkinkan karena keunggulan utama media online adalah pada unsur kecepatan dalam menyebarkan informasi, semakin informasi itu cepat disampaikan ke khalayak maka semakin baik dan media tersebut disukai oleh khalayak.

Namun

Viva.co.id,

Kompas.com dan

Tribunnewsbali.com dalam menuliskan berita gempa Lombok cenderung memenuhi unsur $5 \mathrm{~W}+1 \mathrm{H}$. Tampaknya ketiga media ini yakin bahwa untuk menjelaskan suatu peristiwa dan khalayak bisa mengerti peristiwa gempa yang terjadi di Lombok adalah dengan menggali 
jawaban-jawabannya dengan menjawab unsur who (siapa), what (apa), when (kapan), where (di mana), why (mengapa) dan how (bagaimana). Unsur lengkap dari sub dimensi kebenaran (truth) telah dipenuhi oleh tiga media online tersebut dalam memberitakan peristiwa gempa Lombok.

Lebih baik lagi jika Viva.co.id, Kompas.com dan

Tribunnewsbali.com menambahkan unsur so what (lalu apa). Maka pertanyaan-pertanyaan yang berkembang seperti apa dampak peristiwa gempa tersebut terhadap orang-orang yang terlibat? Apa pula dampaknya bagi pembaca? Apa yang dibutuhkan pembaca untuk mengerti dan peduli tentang peristiwa gempa yang ditulis itu? Dan masih banyak lagi pertanyaan-pertanyaan yang bisa dikembangkan untuk menyelidiki kedalaman implikasi suatu peristiwa atau situasi. Karena kebanyakan peristiwa tidak berdiri sendiri; mereka terhubung dengan perkembangan dan isu yang menjadi perhatian masyarakat. Tak terkecuali berita bencana yang selalu mengundang ketertarikan masyarakat untuk mengetahui lebih jauh dan bagaimana dampaknya nanti bagi mereka.

Wartawan umumnya memiliki semangat luar biasa ketika meliput kekerasan, tragedi atau bencana. Mereka akan berjuang habis-habisan menjadi yang pertama datang ke lokasi. Tak peduli dengan resiko. Wartawan berlomba berada di lokasi bencana untuk merekam pasca terjadinya peristiwa alam yang memporak-porandakan kehidupan masyarakat korban bencana. Wartawan juga berlomba agar bisa mewawancarai korban di lokasi bencana ketika masih dalam kondisi paling parah, semata-mata untuk memperkuat laporan pandangan mata.

Disadari atau tidak, detak jantung dari jurnalisme terletak pada sumber berita. Menjadi wartawan berarti ia mampu mencari sumber informasi. Wartawan harus tahu banyak. Dia harus tahu ke mana mencari informasi dan siapa yang harus ditanya. Seringkali untuk mendapatkan informasi, wartawan harus bergerak keluar batas-batas dari peristiwa itu. Hal ini bisa melibatkan pekerjaan seperti membuka kliping, atau terlibat pekerjaan yang kompleks seperti menghubungi sejumlah sumber untuk konfirmasi, reaksi atau penjelasan. Selain itu wartawan dituntut kreatif untuk mendapatkan kebenaran dan mengungkapkannya. Borjesson mengatakan bahwa pers terkadang tidak mempunyai pilihan lain kecuali menerima pernyataanpernyataan dari sumber resmi seperti apa adanya (Ishwara 2011, 91-94).

Hasil penelitian menunjukkan bahwa Viva.co.id, Kompas.com, dan Tribunnewsbali.com menempatkan unsur penggunaan kutipan wawancara sebagai bagian terpenting dari penegakan sub dimensi kebenaran. Di mana Viva.co.id 
menggunakan kutipan wawancara dalam $86 \%$ beritanya, Kompas.com menggunakan kutipan wawancara dalam $94 \%$ beritanya, dan Tribunnewsbali.com menggunakan kutipan wawacara dalam $96 \%$ beritanya.

Penggunaan kutipan wawancara dari narasumber sangat diperlukan untuk memperkuat fakta atau sebuah fenomena. Menurut $\mathrm{J}$ Anto dalam bukunya Meretas Jurnalisme Damai di Aceh: Kisah Reintegrasi Damai dari Lapangan, jurnalis mendapatkan informasi dari pelbagai kalangan. Caranya adalah dengan bertanya secara formal atau informal. Asal informasi inilah yang disebut narasumber. Semakin banyak narasumber untuk sebuah berita akan lebih baik sebab kemungkinan akan lebih beragam versi yang bisa dipertimbangkan untuk digunakan. Yang ideal adalah satu berita banyak narasumber: bukan sebaliknya, satu narasumber banyak berita (2007:77). Penggunaan kutipan wawancara sangatlah penting dalam suatu berita. Sebab observasi wartawan di lapangan tidaklah cukup untuk menyusun suatu berita tanpa didukung dengan kutipan wawancara dari narasumber yang relevan dan terpercaya. Apalagi peristiwa atau fakta yang hendak dilaporkan adalah peristiwa bencana alam yang perlu didukung oleh keakuratan informasi dari sumber-sumber resmi. Misalnya tentang kronologis peristiwa terjadinya gempa, berapa banyak jumlah korban yang luka maupun tewas akibat bencana, seberapa besar kerugian yang diderita masyarakat korban bencana hingga sejauh mana upaya penanganan yang telah dilakukan oleh pemerintah di lokasi bencana. Semua itu membutuhkan data lengkap yang bersumber dari sejauh mana kemampuan wartawan (penulis berita) pada media bersangkutan dalam menggali informasi sebanyak-banyaknya.

Terkait data korban gempa yang tewas atau hilang dan berapa banyak jumlah pengungsi yang masih simpang siur misalnya, para wartawan harus mengorek sendiri data tersebut dari rumah sakit, PMI, dan atau tempat lainnya, ditambah dengan pengamatan langsung di jalan-jalan dan kuburan massal (Arif, 2010:78)

\section{Media Harus Netral Dalam Memberitakan Peristiwa Bencana \\ Disiplin reportase obyektif} mengharuskan suatu pendekatan yang tidak memihak dalam mengumpulkan dan menyajikan fakta. Wartawan tidak terlibat dalam berita; mereka adalah pengamat yang netral (Ishwara, 2011: 68). Menurut Michael Bugeja, pengajar jurnalisme di Iowa State, objektivitas adalah melihat dunia seperti apa adanya, bukan bagaimana yang Anda harapkan semestinya (dalam Luwi Ishwara, 2011:67). 
Banyak

masyarakat

menemukan berita melalui media online yang dianggap tidak mengedepankan netralitas antara lain ketepatan, kelengkapan, keadilan berita dan hanya untuk mengejar kecepatan terbit saja. Kadang-kadang hal ini yang menjadi penyebab masalah karena media online sangat memungkinkan penyebaran informasi menjadi lebih cepat daripada media lainnya, namun di sisi lain kecepatan ini meninggalkan prinsip-prinsip dasar jurnalisme diantaranya ketepatan berita, wartawan kurang mengecek sumber berita yang komprehensif (Lestari, Ramadhaniyanto, \& Wardyaningrum, 2018).

\section{Tabel 3}

Unsur Netralitas Berita Bencana di viva.co.id

Periode 5 - 11 Agustus 2018

\begin{tabular}{|c|c|c|c|c|c|c|c|}
\hline \multirow[t]{2}{*}{ No. } & \multirow[t]{2}{*}{ Butir } & \multicolumn{2}{|c|}{ Viva.co.id } & \multicolumn{2}{|c|}{ Kompas.com } & \multicolumn{2}{|c|}{ Tribunnewsbali.com } \\
\hline & & $\mathbf{F}$ & $\%$ & $\mathbf{F}$ & $\%$ & $\mathbf{F}$ & $\%$ \\
\hline 1. & $\begin{array}{l}\text { Menggunakan kata- } \\
\text { kata yang } \\
\text { mengandung makna } \\
\text { berlebihan }\end{array}$ & 86 & $65 \%$ & 30 & $26 \%$ & 76 & $72 \%$ \\
\hline 2. & $\begin{array}{l}\text { Tidak menggunakan } \\
\text { kata-kata yang } \\
\text { mengandung makna } \\
\text { berlebihan }\end{array}$ & 47 & $35 \%$ & 83 & $74 \%$ & 30 & $28 \%$ \\
\hline 3. & $\begin{array}{l}\text { Membumbui kutipan } \\
\text { narasumber dengan } \\
\text { memberikan tanda } \\
\text { atau penekanan khusus } \\
\text { '...' (tanda kutip) }\end{array}$ & 132 & $99 \%$ & 8 & $8 \%$ & 94 & $87 \%$ \\
\hline 4. & $\begin{array}{l}\text { Tidak membumbui } \\
\text { kutipan narasumber } \\
\text { dengan memberikan } \\
\text { tanda atau penekanan } \\
\text { khusus '...' (tanda } \\
\text { kutip) }\end{array}$ & 1 & $1 \%$ & 104 & $92 \%$ & 12 & $13 \%$ \\
\hline 5. & $\begin{array}{l}\text { Menggunakan kata } \\
\text { dan kalimat yang } \\
\text { menimbulkan efek } \\
\text { traumatis untuk } \\
\text { menggambarkan } \\
\text { kekuatan gempa yang } \\
\text { luar biasa; } \\
\text { menggunakan kata } \\
\text { yang meyentuh } \\
\text { emosional manusia }\end{array}$ & 92 & $69 \%$ & 46 & $41 \%$ & 74 & $70 \%$ \\
\hline 6. & $\begin{array}{l}\text { Tidak menggunakan } \\
\text { kata dan kalimat yang } \\
\text { menimbulkan efek } \\
\text { traumatis untuk }\end{array}$ & 41 & $31 \%$ & 67 & $59 \%$ & 32 & $30 \%$ \\
\hline
\end{tabular}




\begin{tabular}{|l|l|c|c|c|c|c|c|}
\hline & $\begin{array}{l}\text { menggambarkan } \\
\text { kekuatan gempa yang } \\
\text { luar biasa; } \\
\text { menggunakan kata } \\
\text { yang meyentuh } \\
\text { emosional manusia }\end{array}$ & & & & & & \\
\hline 7. & $\begin{array}{l}\text { Mengangkat kisah } \\
\text { korban bencana mulai } \\
\text { dari upaya } \\
\text { penyelamatan diri } \\
\text { hingga kisah pilu } \\
\text { korban }\end{array}$ & 101 & $76 \%$ & 37 & $33 \%$ & 75 & $71 \%$ \\
\hline 8. & $\begin{array}{l}\text { Tidak mengangkat } \\
\text { kisah korban bencana } \\
\text { mulai dari upaya } \\
\text { penyelamatan diri } \\
\text { hingga kisah pilu } \\
\text { korban }\end{array}$ & 32 & $24 \%$ & 76 & $67 \%$ & 31 & $29 \%$ \\
\hline
\end{tabular}

Sumber: Diolah dari Data Primer (2019)

Ada hal yang menarik dari temuan hasil penelitian dalam kategori netralitas. Hasil penelitian menunjukkan bahwa hanya Kompas.com yang menegakkan sub dimensi netralitas. Di mana berita bencana gempa Lombok di Kompas.com didominasi unsur tidak membumbui kutipan narasumber dengan memberikan tanda atau penekanan khusus '...' (tanda kutip) sebanyak $92 \%$; unsur tidak menggunakan kata-kata yang mengandung makna berlebihan sebanyak $74 \%$; dan unsur tidak mengangkat kisah korban bencana mulai dari upaya penyelamatan diri hingga kisah pilu korban sebanyak 67 \%. Dalam hal ini, Kompas.com tidak memberikan muatan sensasional atau dramatisasi yang bisa diangkat dari peristiwa gempa Lombok. Sehingga tidak mengincar nilai jual untuk mengejar kepentingan ekonomi media untuk menarik perhatian pengiklan. Kompas.com memberitakan peristiwa yang terjadi sesuai dengan fakta yang terjadi tanpa melebih-lebihkan isi berita.

Beda halnya temuan penelitian pada Viva.co.id dan Tribunnewsbali.com yang cenderung mengabaikan sub dimensi netralitas. Ini terlihat dari besarnya presentase unsur yang tidak memuat sub dimensi netralitas yang ditemukan di Viva.co.id dan di Tribunnewsbali.com. Viva.co.id misalnya, ditemukan unsur membumbui kutipan narasumber dengan memberikan tanda atau penekanan khusus '...' (tanda kutip) dengan presentasi kemunculan sebanyak 132 kali (sebanyak $99 \%$ ). Kemudian diikuti unsur mengangkat kisah korban bencana mulai dari upaya penyelamatan diri hingga kisah pilu korban (sebanyak 76 \%). Dan 
unsur menggunakan kata dan kalimat yang menimbulkan efek traumatis untuk menggambarkan kekuatan gempa yang luar biasa; menggunakan kata yang meyentuh emosional manusia (sebanyak 69 \%).

\section{Sedangkan}

Tribunnewsbali.com ditemukan ada unsur membumbui kutipan narasumber dengan memberikan tanda atau penekanan khusus '...' (tanda kutip) sebanyak $87 \%$. Kemudian diikuti unsur menggunakan kata-kata yang mengandung makna berlebihan sebanyak $72 \%$. Dan unsur mengangkat kisah korban bencana mulai dari upaya penyelamatan diri hingga kisah pilu korban sebanyak 71 $\%$.

Viva.co.id dan

Tribunnewsbali.com tampaknya tak bisa melepaskan diri sepenuhnya dari kepentingan ekonomi media. Di mana muatan sensasional atau dramatisasi yang bisa diangkat dari peristiwa gempa Lombok memiliki nilai jual yang tinggi untuk menarik perhatian pengiklan. Sehingga kisah pilu korban bencana merupakan sisi yang menarik untuk diberitakan dibanding memberitakan peristiwa atau fakta itu apa adanya. Tak heran jika peneliti banyak menemukan kemunculan penggunaan kata-kata yang mengandung makna berlebihan, seperti kata miris, tragis, kesedihan, kesakitan, penderitaan, ketakutan, porak poranda, dan kata sensasional lainnya. Dan bukan hanya itu saja, peneliti juga menemukan adanya unsur membumbui kutipan narasumber dengan memberikan tanda atau penekanan khusus '...' (tanda kutip). seperti kata 'ditemukan', istilah ''cincin api', kalimat "jangan mati', , dan penekanan lainnya.

\section{Peran Media Online Dalam Memberitakan Gempa Lombok \\ Pemberitaan bencana melalui} media online dapat mengurangi risiko bencana karena sudah adanya kesiapsiagaan dari masyarakat untuk mengurangi akibat dari bencana yang terjadi. Menurut Undang-Undang Nomor 24 Tahun 2007 tentang Penanggulangan Bencana (Presiden Republik Indonesia, 2007) telah membawa pergeseran paradigma dalam penanggulagan bencana dari hanya menanggapai situasi saat bencana terjadi (tanggap darutat) ke pencegahan dan pengurangan risiko bencana (PRB). Selain itu, pada pasal 21 dicantumkan bahwa Badan Penanggulangan Bencana Daerah mempunyai tugas menyusun, menetapkan, dan menginformasikan peta rawan bencana. Sementara pada pasal lainnya disebutkan bahwa setiap orang berhak untuk mendapatkan informasi secara tertulis dan/atau lisan tentang kebijakan penanggulangan bencana dan berkewajiban untuk memberikan informasi yang benar kepada publik tentang penanggulangan bencana. 
Ketentuan undang-undang tersebut menyebutkan bahwa media merupakan salah satu pemangku kepentingan yang memiliki peran penting untuk menyebarluaskan informasi tentang kebijakan dalam pencegahan dan pengurangan risiko bencana (Lestari, P., Ramadhaniyanto, B., \& Wardyaningrum, D., 2018).

Viva.co.id, Kompas.com, dan Tribunnewsbali.com yang merupakan portal berita online yang banyak diakses masyarakat sebenarnya sudah menjalankan perannya, terutama dalam memberitakan terjadinya bencana alam untuk memenuhi kebutuhan informasi pembacanya. Viva.co.id, Kompas.com dan Tribunnewsbali.com menyadari bahwa peran pers sangat penting dalam memberitakan terjadinya bencana alam secara benar dengan tetap mengutamakan prinsip-prinsip jurnalisme, terutama unsur objektivitas.

Peristiwa bencana alam adalah peristiwa historis yang sangat membekas, masyarakat selalu ingin tahu dan butuh informasi tentang berbagai hal mengenai bencana yang terjadi, penyebab, korban, kerugian, dampaknya secara luas, penanggulangan dan lainnya. Kemudian masyarakat memuaskan rasa ingin tahunya dengan mengkonsumsi berbagai media yang ada (Rahayu, Polysemia, Juli 2006).

Media adalah saluran yang efektif untuk menyebarkan informasi terkait bencana alam ke berbagai penjuru dunia. Semua informasi tersebut dapat terekam dan tersampaikan dengan cepat melalui pemberitaan media, terutama jika menggunakan media online sebagai sarananya. Artinya Viva.co.id, Kompas.com dan Tribunnewsbali.com telah menjalankan fungsi informatifnya. Namun yang perlu disiasati dari fungsi informatif ini adalah media dapat berperan memberikan informasi positif maupun negatif mengenai berbagai bencana di sekitar masyarakat. Informasi positif dapat memberikan kepercayaan kepada masyarakat mengenai kebenaran suatu berita. Informasi negatif berpotensi menimbulkan isu yang tidak jelas kebenarannya. Masyarakat dapat terpengaruh dengan berita negatif tersebut dan menimbulkan suasana panik (Wahyuni, 2008).

Bila dikaitkan dengan pemberitaan bencana, informasi yang positif dapat berperan dalam menyediakan informasi yang akurat dan terpercaya pada warga masyarakat, baik yang menjadi korban bencana maupun yang bukan korban bencana. Informasi positif memungkinkan terjadinya proses pemulihan kehidupan masyarakat korban bencana berjalan dengan cepat. Informasi positif memungkinkan masyarakat korban bencana untuk segera bangkit dari kesedihannya, apalagi jika media tersebut lebih banyak menyampaikan 
pesan-pesan yang sarat muatan optimisme.

Salah satu prinsip jurnalisme yang disebutkan Bill Kovach dan Tom Rosenstiel dalam bukunya berjudul, The Elements of Journalism, loyalitas pertama jurnalisme adalah kepada warga masyarakat. Artinya, wartawan harus memelihara kesetiaan kepada warga masyarakat dan kepentingan publik yang lebih luas dalam memberitakan suatu fakta/peristiwa, tanpa rasa takut atau memihak. Komitmen kepada warga masyarakat ini adalah basis kepercayaan organisasi media. Media harus dapat mengatakan dan menjamin kepada khalayaknya bahwa liputan bencana yang dilakukannya itu tidak diarahkan untuk menutupi sesuatu atau untuk mendatangkan pemasang iklan. Kepercayaan inilah yang nantinya dapat membangun khalayak yang lebih luas dan loyal. Dan kemudian, ini akan berdampak pada sukses ekonomi media itu sendiri.

Peran lainnya dari pemberitaan bencana di Viva.co.id, Kompas.com dan Tribunnewsbali.com adalah ketiga media ini mampu melakukan fungsi mengaitkan (linkage) kelompok-kelompok masyarakat yang terpisah secara geografis untuk kemudian tanggap terhadap peristiwa bencana alam. Fungsi linkage ini memungkinkan kelompok-kelompok masyarakat yang terpisah secara geografis tersebut dapat dimobilisasi dengan cepat untuk segera memberikan bantuan pada korban bencana. Viva.co.id dan Kompas.com bahkan aktif memberitakan bantuan apa saja yang sangat dibutuhkan korban bencana dan pihak-pihak mana saja yang telah mendatangkan bantuan untuk masyarakat korban bencana.

\section{SIMPULAN}

Berdasarkan analisis temuan penelitian diperoleh simpulan bahwa Viva.co.id, Kompas.com dan Tribunnewsbali.com mengutamakan sub dimensi kebenaran dalam menegakkan obyektivitas. Sub dimensi kebenaran terbagi dalam tiga unsur, yaitu faktual, akurasi dan lengkap. Ketiga unsur dari sub dimensi kebenaran ini seluruhnya dipenuhi oleh Viva.vo.id, Kompas.com dan Tribunnewsbali.com dalam memberitakan bencana gempa Lombok. Namun Viva.co.id dan Tribunnewsbali.com mengabaikan sub dimensi netralitas, sedangkan Kompas.com tidak mengabaikan sub dimensi netralitas. Sub dimensi netralitas adalah bagian dari dimensi objektivitas. Ada hal yang menarik dari kategori netralitas.

Viva.co.id, Kompas.com, dan Tribunnewsbali.com sudah menjalankan peran informatif dalam memberitakan bencana gempa Lombok untuk memenuhi kebutuhan informasi khalayaknya. Viva.co.id, Kompas.com dan Tribunnewsbali.com menyadari 
bahwa peran pers sangat penting dalam memberitakan terjadinya bencana alam secara benar dengan tetap mengutamakan objektivitas dan menegakkan prinsip-prinsip jurnalisme, seperti prinsip kebenaran, akurasi dan netralitas. Peran lainnya yang dilakukan Viva.co.id, Kompas.com dan Tribunnewsbali.com dalam pemberitaan gempa Lombok adalah mampu melakukan fungsi mengaitkan (linkage) kelompokkelompok masyarakat yang terpisah secara geografis untuk kemudian tanggap terhadap peristiwa bencana alam. Fungsi linkage ini memungkinkan kelompok-kelompok masyarakat yang terpisah secara geografis tersebut dapat dimobilisasi dengan cepat untuk segera memberikan bantuan pada korban bencana.

Saran yang diberikan bahwa penelitian ini memberi tambahan pengetahuan kepada pembaca bahwa masih ada media online yang memberitakan tentang bencana gempa Lombok secara obyektif dengan menegakkan prinsip-prinsip jurnalisme. Penelitian ini juga memberi masukan kebijakan pada Viva.co.id, Kompas.com dan Tribunnewsbali.com agar lebih bertanggungjawab dalam menyiarkan berita, terutama dalam hal objektivitas berita melalui penegakan prinsip jurnalisme. Bukan dengan menggunakan unsur dramatisasi dan unsur traumatis sebagai nilai jual berita.

\section{DAFTAR PUSTAKA}

\section{Buku:}

Arif, Ahmad. (2010). Jurnalisme Bencana, Bencana Jurnalisme

: Kesaksian dari Tanah

Bencana. Jakarta:

Kepustakaan Populer

Gramedia.

Eriyanto. (2011). Analisis Isi : Pengantar Metodologi untuk Penelitian IImu Komunikasi dan Ilmu-ilmu Sosial Lainnya. Jakarta: Kencana Prenada Media.

Ishwara, Luwi. (2011). Jurnalisme Dasar, Jakarta, Kompas.

Kriyantono, (2010). Teknik Praktis Riset Komunikasi, Jakarta, Kencana Prenada Media Group, 2010).

McQuail, Denis, dan Sven Windahl. (1996). Communication Models for the Study of Mass Communications. Edisi ke-2. London, Longman.

Suryawati, Indah. (2011). Jurnalistik Suatu Pengantar: Teori dan Praktik. Bogor: Ghalia Indonesia.

Sobur, Alex. (2006). Analisis Teks Media: Suatu Pengantar Untuk Analisis Wacana, Analisis Semiotik, dan Analisis Framing. Bandung: PT Remaja Rosdakarya. 
Sumber lain:

https://www.bnpb.go.id/home/sistem

Aisyah, S. Pantow, J.T., dan Koagouw, F.V.I. (2015). Peran media online dalam meningkatkan prestasi belajar. E-journal Acta Diurna Ilmu Komunikasi Fisipol Universitas Sam Ratulangi, IV(4), 1-9.

Gama, B. (2010). Jurnalisme bencana dan rangsangan emosional : studi hubungan jurnalisme bencana banjir surat kabar Solopos dengan rangsangan emosional mahasiswa, Univet Bantara Sukoharjo. Scriptura, 3(1), 8-18. https://doi.org/10.9744/script ura.3.1.8-18.

Lestari, P., Ramadhaniyanto, B., \& Wardyaningrum, D. (2018). Pemberitaan di Media Online Untuk Pengurangan Risiko Bencana Gunung Sinabung. Jurnal Kajian Komunikasi, 6(1), 106-120.

Lumowa, Fernando. (2017). Media Online: Teknik Dasar Penulisan Berita, Arlikel dan
Bahasa

Jurnalislik, sulut.kemenag.go.id/file/file/h umas/zuvw 1339679719. ppsx Pramudhiarta, N. \& Permanasari, A.C. (2014). Penerapan knowledge management system berbasis web sebagai sistem pendukung pengambilan keputusan (dss) dalam pengurangan risiko bencana di Indonesia. Jurnal Dialog Penanggulangan Bencana, 1(1), 1-10. Diakses dari bnpb.go.id

Rahayu, (2006). Refleksi: Fungsi Media di Negara Rawan Bencana, Jurnal Polysemia, Edisi 3, Juli 2006.

Wahyuni, H.I. (2008). Kecenderungan 'Framing', Media Massa Indonesia Dalam Meliput Bencana Sebagai Media Event. Jurnal Komunikasi Fisipol UGM, Yogyakarta, 1-22. https://doi.org/10.22146/jsp. 10990. 